\title{
Calculation in the pirate bazaars
}

\author{
Maitrayee Deka \\ Department of Social and Political Sciences, University of Milan, Milan, Italy
}

\begin{abstract}
Recent debates in economic sociology have focused on the question of long-term calculation specific to capitalism. With a renewed interest in Max Weber's work, particularly his seminal essay, The protestant ethic and the spirit of capitalism, scholars such as Arjun Appadurai and Jens Beckert have analysed calculative devices intrinsic to long-term accounting. Appadurai highlights the charismatic figure of the financial player who speculates on uncertainty, the same realm of uncertainty that in Beckert's work becomes intelligible through the creation of market fictions. In this paper, I instead explore calculation as it unfolds in bazaars selling contraband and pirated electronic goods. Based on an ethnographic account of Delhi's Lajpat Rai market, Palika Bazaar, and Nehru Place, I argue that calculation in the pirate bazaars is of a short- term nature and oriented to an embedded economic rationality that is closely entangled with the longue durée of everyday life. Rather than future-oriented fictions, small-scale traders employ moral stories and piracy-related discourses to meet day-to-day survival needs.
\end{abstract}

KEYWORDS Calculation; piracy; bazaars; ethics; survival

\section{Introduction}

Recent social theory has focused on calculation as a constitutive element of social and, in particular, economic action. For Michel Callon, markets should be understood as 'collective calculative devices' that function precisely because they institutionalise ways of transforming qualities into quantities, and thus enable particular forms of rationality to operate (Callon 1998, Callon and Muniesa 2005). Calculation concerns the routines and rituals that constitute human interaction and relationships in different economic systems.

According to Callon and Muniesa, "calculation starts by establishing a distinction between things or states of the world, and by imagining and estimating courses of action associated with those things or with those states as well as their consequences' (2005, p. 1231). In this spirit, Arjun Appadurai (2012) has urged us to focus on what he calls the 'spirit of calculation', which is a historically contingent, and wider calculative frame within which a particular economic system operates. Building on Max Weber's work, Appadurai uses this expression as a way of conceptualising the present evolution of capitalism, from an industrial to a financial form, where profits derive from a different ordering of economic relations.

Appadurai's work concentrates on how calculation operates in the capitalist economy. This focus is common to most recent work in economic sociology, where there is little or no attempt to distinguish between specifically capitalist forms of calculative rationality and the logics of market action in general. Particular to such 'capitalist calculation' is its focus on incorporating the future. Whether through formalised accounting techniques such as double-entry bookkeeping, or by means of 'fictions', 'virtual futures' or other projections, the basic insecurity of the future is rendered calculable 
and, hence 'actionable'; internalised into present economic actions as an object amenable to rational calculation (Knight 1921, Arnoldi 2004, Esposito 2011, Beckert 2013). In his recent work, Jens Beckert (2013) has developed the notion of fictions and fictional action as a way of understanding economic action. Fictional accounts such as corporate strategies or expert predictions of stock market developments postulate a fictional future - fictional in the sense that it is developed without a 'serious' commitment to empirical facts. However, there is reason to believe that the ability to create shared and 'stable' fictions about the future, and in particular about the future of markets, has become a more important ingredient of (successful) capitalist accumulation in the information economy in particular. This is because fictions allow for the coordination and calculation of economic action outside the boundaries of organisations. In Marazzi's words, they enable the bio-political control of a multitude of actors (Marazzi 2008).

However, not all of the world's economy is capitalist (Braudel 1984). And calculation also operates in what Fernand Braudel (1982) calls 'market economy', an economy marked by high levels of competition and transparency, low profits, and very little capital investment. Braudel (1977) offers a tripartite model of economic systems. At the highest level, we find capitalism, comprising high finance and monopolies, followed by the market economy of small exchanges and low investment. At the bottom, we find material life, embedded in the longue durée and 'little touched by the obstinate erosion of time' (Braudel 1981, p. 23).

At these different levels of economic life, calculative methods and devices are different; what remains constant, however, is the very act of calculation and the need to estimate different goods and their value. The way in which financial actors calculate through complex algorithms is very different from the ways in which market traders calculate. The calculation of financial actors is oriented towards making the future intelligible (Appadurai 2011). In contrast, the calculative mechanisms of small traders are not aimed towards the future. Most of their energy goes into making the present accountable and optimising everyday market exchanges. Day-to-day bookkeeping and haggling become important calculative mechanisms to gauge one day against the next.

The different layers of economic life are not impenetrable. Braudel argues that when capitalism emerges as a dominant economic system, it exerts pressure on the market economy and makes it susceptible to the hegemonic accord struck between capitalists and state actors (Braudel 1982). Similarly, the market economy impinges on everyday life and vice versa.

Economic sociology and anthropology have tried to elucidate the interaction between economic action and everyday life. Karl Polanyi's classic work, The Great Transformation, argues that selfinterested market actors are not a universal category (Polanyi 1975). Polanyi (1975) takes a 'substantivist' approach and examines in preindustrial society,

the actual processes through which the society provides itself with food, shelter, and other material goods, bearing in mind this process is entirely embedded in society and not a sphere of activity that can be distinguished from say, politics, kinship or religion. (Graeber 2001, p. 11)

With the development of markets, Polanyi sees a disembedding of the economy from society and the emergence of an individualised market actor.

In the case of India, studies have used the frame of embeddedness to show how kinship, religious, and community ties govern economic action (Vidal 2003). However, more recent works have taken issue with this relationship between market behaviour and everyday life. Vidal suggests that one needs to avoid both an undersocialised and oversocialised approach to the study of economic activity. Rather, the real challenge for an anthropologist is to investigate how rational calculations interact with social norms to create a particular type of economic actor (Vidal 2000).

For instance, Ritu Birla's work highlights the small yet delicate distinction between the cultural and economic sphere that defines commerce in South Asia. She argues that during colonial rule, Marwari businessmen did not use kin networks out of an obligation to community ties, nor did they see these networks as a 'burden'. They sustained extensive kin networks to promote trade advancement (Birla 2011). In this regard, the notion of Homo Economicus, economic man, is not 
alien in India (Birla 2010). Traders and merchants alike maximised their self-interests, and made the best possible use of scarce resources. The relationship of economic activities with the longue durée is one where each informs and impacts the other, with neither losing its definite sphere of influence.

Weber's (2001) The protestant ethic and the spirit of capitalism is an example of how a religious institution prompted an environment conducive to capitalism. Weber argues that Protestant ideals such as beruf (calling) favoured a life of discipline, and economising that in turn led to the spirit of incessant accumulation of profit. Further, the Calvinist doctrine of predestination, by which a selected few were chosen for salvation, was the 'dogmatic background of Puritan morality in the sense of methodologically rationalized ethical conduct' (Weber 2001, p. 77). More recently, Appadurai (2012) has attempted to reinstall Weber at the heart of contemporary discussions on capitalism by co-opting magic, charisma, and irrational speculation into the realm of high finance.

If we were to analyse a similar interrelationship between businesses of 'small profits' and everyday life, we see the lived traditions of religions and morality exerting an impact on economic life. Unlike the direct link that Weber observed between Protestantism and capitalism, the relationship between Hindu morals and bazaar commerce is much more complex. Bazaar traders allude to a religious morality that has its roots in texts and institutions as well as in century-old oral traditions (Babb 1987, Madan 1987). They borrow from myths, folklore, and everyday conversations to formulate what according to them constitutes a moral self. As far as Hindu scriptural influences are concerned, rather than an orthodox reading of sacred texts, it is the traders' own interpretations that take precedence.

As is the case in most parts of India, lived Hinduism is of a syncretic nature. It draws its legitimacy from myriad sources, most of which are legitimised through everyday experiences. In this regard, ethics become a more useful frame to articulate the fluid Hindu myths and moral stories that circulate in the bazaars. The 'context-specific' elaboration of traders' lives shows how they formulate an ethical being through moral stories (Pandian 2010).

The scope of this essay is mainly ethnographic and descriptive. After a brief section on methodology, I will present a thick account of the day-to-day calculation of the traders in Delhi's bazaars. This is followed by a discussion on the bazaar ethics that bring together everyday understandings of Hindu myths/stories and discourses on piracy. The conclusion will briefly re-connect my results to contemporary discussions on calculation, capitalism, and markets.

\section{Methodology}

Delhi's electronic markets, Lajpat Rai market, Nehru Place, and Palika Bazaar, are part of a non-agricultural informal economy that absorbs about $62 \%$ of the Indian population (as of the 2000s). The informal economy as a whole accounts for about $90 \%$ of the Indian workforce (Kalyani 2015). It is defined by a lack of fixed term contracts and labour protections. Within the informal economy, businesses are run by household capital. They typically do not employ more than 10 workers (Amin 2002). The term 'bazaar' is used in the essay to describe a certain type of informal economy, where face-to-face bargaining and informal regulations govern economic actions (Geertz 1978).

Lajpat Rai market is a crowded bazaar in the Chandni Chowk area of Old Delhi. Overlooking the historic Red Fort, it is a wholesale market that sells various types of electronic commodities including video games. Established in 1978, Palika Bazaar was the first underground air-conditioned market in India. Situated in the central district of Delhi, Palika Bazaar has a circular infrastructure, with the majority of video game shops situated in the inner circle of the edifice. Built in the 1970s, Nehru Place became a hub for selling computer hardware and software in the 1990s. Riding on the boom in computer sales, street vendors started selling pirated CDs/DVDs of software and computer games in the market.

Initially, I conducted a 12-month session of fieldwork between September 2012 and September 2013. I revisited the markets in January 2015 and later in the months, March and April 2016. I interviewed close to 15 traders in Lajpat Rai market. I interacted with approximately 30 traders and shop 
assistants in Palika Bazaar. In Nehru Place, I interacted with about 50 street vendors. I conducted intensive interviews with each of them. Apart from structured interviews, free flowing conversations were an integral part of the fieldwork. With a handful of traders and street vendors, I developed a special rapport, which meant that conversation over an extended period of time became possible. Apart from interviews and conversations, I also engaged in observation-based ethnography. I spent three to four hours a day alternating between the markets. Half of this time was spent observing how the traders interacted with consumers coming to the shops. I was also privy to the conversations amongst traders and between traders and distributors coming to the market.

\section{Calculation in the pirate bazaars}

\section{Day-to-day bookkeeping and uncertain assets}

In Lajpat Rai market, Bharat looks up from a piece of white paper, as the supplier comes to his shop to settle the day's business. In the past week, from different suppliers, he has stocked up on hundreds of cartridges of Angry Birds, 'Made in China' handheld video games and adaptors. On most days, Bharat settles the day's business in the evening, preferably after seven. By that time, he has already made the majority of his sales and can make a good judgement on whether it is wise to keep a particular stock of product. Bharat rarely sells all his stock in a single day. However, having spent some time in the market, he realises that if a new product sells well on the first day, there is a good chance that it will also sell well in the future.

On that particular day, Bharat is preoccupied with the fresh stock of adaptors for video games. Although he thought there would be a huge demand for the new adaptors, he did not sell any item on the first day. So when the supplier comes to his shop, he wants to return the stock. The supplier is reluctant to do so. He is more interested in getting the money for his goods. Bharat asks for an extra day to make the payment. He explains to the supplier that the market as a whole has stagnated and his business is poor.

After the supplier leaves, Bharat turns to me and shows me the intricate calculations written on the little piece of paper in front of him. On it, he has the names of the different suppliers and the quantity of goods that he has borrowed from each one of them. In another column, haphazardly drawn by a blue ink pen, Bharat jots down the sum of money he owes to the suppliers. He says to me that he is tired of the slow market. Bharat recollects a time when no matter how many goods he acquired, they sold out in a day or two.

The time spent browsing through the list and confronting different suppliers is a daily ritual for Bharat. The visits from suppliers at the end of the day act as a reminder of how well or badly his day has gone. Usually, he pays the person on the same day. But sometimes, he asks for an extra day to create some space for negotiation. Whoever comes out happiest, Bharat and his supplier always manage to strike a deal within a couple of days. He either pays the supplier or manages to return the borrowed goods.

This day-to-day bookkeeping contrasts with Bharat's inability to make any clear estimation of his assets. Every day a struggle ensues to conduct a certain number of transactions and pay off the suppliers. The trader tries his best to make a profit after he has paid his debts. In such a situation, it is difficult for him to make a long-term estimation of his business success and what he can mark as assets. The fear of having unsold stock bought from depleting income dissuades the traders from spending huge sums of money on expensive products and diverts limited savings to other investments. The Chinese knock-offs, recycled consoles, and second-hand games become substitutable commodities that permit traders to make a living without having to take serious risks. The 'use and throw away' variety of goods go hand in hand with the precarious income source of the traders. Jack

Goody (1996) observes that Indian businessmen were among the earliest to use the double- entry bookkeeping methods associated with the growth of capitalism. Their contemporary compa- triots, the petty traders in Delhi marketplaces, are far from adopting the capitalist habit of keeping 
track of long-term assets and liability when most of their concerns are attuned towards survival in the immediate present.

\section{Haggling and price determination}

Bazaar traders use calculative haggling techniques to increase the chances of a successful transaction. The following conversation in Govind's shop in Palika Bazaar records the exchanges between a trader and his consumer.

Govind:

Consumer:

Govind:

Consumer:

Govind:

Consumer:

Govind:

Consumer:

Govind:

Consumer:

Govind (pointing to his assistant says in a jocular tone):

Assistant:

Assistant to Govind (in a loud voice making sure that the consumers are listening):
Come here! What are you looking for? (Govind addresses a group of young men; one of them takes lead in the succeeding conversation).

I want to sell a used PlayStation 3 DVD of Grand Theft Auto $\mathrm{V}$

How many times have you used it? I hope there are no scratches.

I have played it once. It is in great shape.

How much do you want for it?

1600 rupees (24\$). I bought it for $3000(60 \$)$

Kid! Are you coming to the market for the first time? Do you have any idea of the present rates for used DVSs? Give us a decent price! We are not paying more than 900 rupees $(18 \$)$ (Slighted by Govind calling the consumer a 'kid', there is some commotion in the group. They are contemplating whether to stick to the shop or try another one. Making a last attempt, the consumer confronts Govind with additional information).

We have checked the price on OLX (a website for secondhand goods). It will pay us 1500 (30\$).

Do you even know how it is to deal with OLX? It will first list your DVD online and then wait for interested consumers. If the website gets any response, they will first forward your phone number to the interested person. After that it is your headache to arrange a meeting and give the buyer your product. On top of that, you have to ensure that you get paid the correct amount for the product. It is not automatic!

We know the process; that is why we have come to your shop. But we want at least 1200 .

(Govind realizes that his scheme of direct bargaining and belittling the consumers was not working in his favour and decides to change his strategy altogether. He shifts the topic of conversation).

Look at him, how thin he is! Don't you want to treat us with something to eat? We can all do with some samosas (Indian snacks) and tea. You all look like nice young men. Come on! You can spare us some money (At this point the assistant getting his cue jumps into the conversation).

How nice of them! We are going to have free evening snack today.

(Meanwhile, Govind calculates how much money would be required to feed everyone at the shop, eight people including me. He quotes the price at $2 \$$ (100 rupees). All the four young men are baffled as they are reluctantly pulled into the new thread of conversation. They were in a way obligated to pay for the tea or appear outrightly disrespectful).

Okay! So we have to pay them 1000 rupees ( $20 \$$ ) after deducting the price for the tea. (The young men are hesitant to accept the bargain. Yet, they realize they cannot do much to get out of it. They take their $20 \$$ and leave the shop). 
In the pirate markets, the calculation behind a transaction is different from formalised spaces such as supermarkets where 'prices and offers do not fluctuate on the spot, but are set in advance' (Cochoy 2007, p. 113). The practice of settling prices through exhaustive bargaining in Delhi's pirate economy resembles what takes place in traditional bazaars. Geertz (1963) touches upon the practice of haggling between buyer and seller in his account of pricing in the pasar in Modjokuto.

\begin{abstract}
Pricing is much more a matter of estimates in a situation where highly specific comparative and historical data are simply not available; instead of exactly calculated prices, one finds the setting of broad limits within which buyer and seller explore together the finer details of the matter through a system of offer and counteroffer. The ability to operate effectively in the gap of ignorance between a price obviously too high and one obviously too low is what makes a good market-trader: skill in bargaining - which includes as its elements a quick wit, a tireless persistence, and an instinctive shrewdness in evaluating men and material on the basis of very little evidence-is his primary professional qualification. (Geertz 1963, p. 33)
\end{abstract}

It is interesting to see that, as in the traditional bazaars, the small-scale traders in Delhi engage in the same repertoire of bargaining to settle prices. This points to the lack of external structures, such as the 'market devices' of advertising and institutions that construct prices. As a result, the factoring in of long-term market fluctuations and demands is minimal. What the bazaar traders have is what is in front of their eyes. The success of their trade depends on what they earn from immediate market exchanges.

\title{
Dehadi (daily wage) 'settings' and everyday security
}

Besides settling credit accounts and formulating strategic bargaining practices, nurturing social ties is another important element of the bazaar calculus. Crucial amongst these are the ties established between the employer and his employee. Furthermore, with local policemen and powerful market actors in play, traders arrange 'settings' (informal monetary arrangements) to create a security net around their businesses.

In Nehru Place, Amrit leads a group of street vendors, about 15 of them, who wait for consumers in the inner most part of the building (at the Delhi metro exit). On most days, Amrit remains behind the scenes. It is Saurav who looks after the trade and manages other street vendors in the group. Saurav is a technician. Whenever the street vendors have problems dealing with a consumer, they come to him for assistance. He is responsible for distributing the dehadi (daily wage), about 300 Indian rupees. Dehadi establishes a relationship of allegiances within the group. Earning the daily wage makes the young street vendors' labour worthwhile and they continue to work under the same group leader.

After paying the young men, Saurav gives the remaining money to Amrit. Once I asked Saurav if he was okay to share the lion's share of profits with Amrit, who made about 3000 rupees daily. He was prompt to reply that Amrit was not money-minded. In case of an emergency, Amrit would not refuse him any help. Saurav said Amrit's job was difficult. He and his group of street vendors would not survive if Amrit did not maintain connections with other people in the market. Saurav pointed out that their business spot was arranged only after Amrit convinced a trader to let the street vendors loiter outside his shop.

Amrit's reputation as a hardworking and sincere person has put him in the good books of many traders in the markets. The social connections developed by Amrit enable the street vendors to enjoy protection from senior traders. Apart from the social ties that Amrit maintains with senior traders, part of his job is to fix 'settings' with the local police constable. These are delicate exchanges. Amrit has to stay alert to see if the constable changes from one day to the next. With the regular constable, things are simpler. After communicating through the prescribed channels, Amrit and the constable can reach an understanding. Amrit knows the sum of money that has to change hands in order for the constable not to raid his stock. However, with new recruits, things are more complicated. The negotiations have to go via several people, in order for both parties' interests to be protected. At times, even with Amrit's efforts at keeping everything under control, things get out of hand. He 
tells me that the most difficult part is when one of his men is arrested. He feels responsible for each one of them and it is hard for him to see someone harassed by the police.

Wages, bribes, and favours are part of the calculation matrix that street vendors use to secure their trade. As in Nehru Place, in Palika and Lajpat Rai, payments are made to the local mafia or powerful traders to ensure the security of businesses. We observed that the traders do not take financial risks, but deal with uncertainties of a circumstantial nature. On a day-to-day basis, they are concerned with whether police will come and raid their stock or whether untoward market incidents will jeopardise their trade. The only way in which they can translate these uncertainties into measurable risks is to renew social ties on a daily basis.

The bazaar traders differ from financial actors in their relationship to the calculation of risks. Most recent accounts of how financial actors manage uncertainties highlight either the role of fictions in converting uncertainties into risk or the charismatic figure of an investor that gambles on uncertainty (Langlois and Cosgel 1993, Beckert 2013). In the bazaars, on the contrary, uncertainties do not offer themselves as financial possibilities; rather, their appearance threatens the traders' business. In this sense, the management of uncertainties is a search for security rather than profit.

\section{Bazaar ethics and moral stories}

The everyday calculus of the traders relates to an ethical universe. As Appadurai notes, '[e]thics, in the Weberian usage, involved a set of linked understandings of means and ends in pursuit of calculative action in a world of uncertainty, with a constantly changing set of cultural orientations that inform and shape these understandings' $(2012$, p. 7). Moral stories are a form of framing that creates a market actor who is satisfied with 'small profits'. They create a unique ethos of co-existence and 'non-sabotage' that goes hand in hand with a short-term calculation matrix.

Manpreet and Govind's video game shops are opposite to each other in the inner circle of Palika Bazaar. Sometimes without any prior announcement, both shops refuse to do business with one another. These incidents occur as the shops are of the same size and are equally popular. It is their way of ascertaining that a new consumer does not unduly favour one shop over the other. While shops of equal size and popularity do not regularly come to each other's aid, the situation is not the same when it comes to small shops dealing with big shops and for that matter when old traders engage with new market actors. It is quite common for a small shop to borrow goods from a big shop.

Even though many of the exchanges amongst traders are mediated by money, it is difficult to pitch all such interactions in monetary terms. Traders look out for one another in times of need. Often with a new entrant to the markets, traders are concerned to help him find him a footing in the market. If the new person also shares other affinities such as belonging to the same town or locality, then established traders go out of their way to help him get his business started. I observed that some acts of looking out for one another are framed in a moral discourse.

\section{We should provide selfless service! (Humeh Niskam Karam Karna Chahiye)}

Vikram, a street vendor in Nehru Place, helped a person from his native Baraut village in Uttar Pradesh to join a group of street vendors in the market. Although the act of helping out an acquaintance has the obvious benefit of creating an expectation of reciprocal help in the future, Vikram justifies his action by referring to the sacred Hindu text, Bhagavat Gita. He mentions how Lord Krishna in the Gita elaborates on the values of 'selfless service'. Vikram justifies his action of helping out a friend in the same register of selfless service, without anticipating favours in the future.

In Palika Bazaar, Govind frowns upon the human tendency toward incessant accumulation of wealth. He tells a story to highlight the benefits of a 'non-sabotage mentality' and a frugal existence. Govind narrates: 
A sage in the Vedic times was curious to know what was the cause of all evils. He decided to pray to God to find out the answer. God revealed to him that a prostitute could give him the correct answer. The sage accordingly went to a prostitute and asked her the same question. She did not give him an immediate reply and said if he wanted to know the answer he should stay with her for a month. The sage agreed to the condition, insisting that he would have his own separate quarters. After a few days, she offered to cook his meals and bring him a gold coin everyday. The sage thought it was not a bad idea and he could dedicate most of his time to other pursuits. Gradually, he started living a domestic life equipped with material comforts. One day he made a proposal to the prostitute to marry him. In the place of one month, seven months had passed. The prostitute as a reply to the sage's question remarked, 'You came here to know what was the cause of all sin, it is greed!' The sage understood everything. Coming into contact with wealth and greed, he had moved away from his previous life of piety.

Govind uses this tale to speak of the evils of greed in business. He values frugality as a virtue. An ethical way of doing business is to be content with basic survival needs and not pursue unbridled accumulation of wealth, and, he adds, thereby sabotage the chances of other market actors. Govind's business aspiration is to be part of a chai bagaan (tea garden) where different trees of the same size flourish. He does not want to be a big tree that casts a shadow on smaller plants, stunting their growth.

\section{Bazaar ethics and piracy}

The ethical life that affects the short-term calculation of the traders is as much a part of circulating Hindu myths as about the institutional discourses surrounding the commodity in circulation. In this regard, we come to speak of piracy. Because of the nature of the commodity sold, in this instance, video games, their illegal downloading and circulation fall under copyright violation. Delhi's small-scale traders have time and again faced police raids that are aimed at confiscating pirated stocks of games and software. As mentioned earlier, business goes on as usual after the traders bribe the local constables to leave them alone. In this regard, piracy, and the legal sanctions against it, has become part of the lived reality of the traders.

The legal definition of IP (intellectual property) laws has become the most dominant definition of piracy. One way of understanding the hegemony of the proprietary rights is by comparing it to the global political and economic environment of neoliberalism. Dent argues that,

\footnotetext{
Applying the label pirate ... allows powerful institutions to decide which actors are allowed to compete in, and which are to be excluded from, mainstream economic practice. This provides these institutions with a moral scheme by which those able to protect their IP are allowed to benefit fully from their economic activity, while those unable to do so are not: an ethics of accumulation. (2012, p. 31, emphasis in the original)
}

However, piracy in reality is a complex phenomenon. Lobato (2014) speaks about piracies to capture the magnitude of practices outside of 'authorised consumptions'. Whether it has to with the illegal downloading of movies at homes, the selling of pirated media on the streets, or the circulation of copyrighted material amongst peers, these practices cannot be framed in a moral discourse of the good or the bad. If piracy is to make any sense at all, it has to be understood on the ground, analysing the people who participate in it and at what cost. For a long time in India, bazaar level piracy has been the focus of scholarly work. From music cassettes to video games, the street level markets have made pirated media part of Indian households. Sundaram's (2010) work highlights the potential of local pirate cultures that not only create modes of livelihood for the participants but also rewrite the limits of urban existence. Liang (2010) highlights the conservatism shrouding piracy, which in reality allows the bazaar actors to negotiate their position in an informal 'political society'. Despite having a radical potential, he concedes that piracy has been outcast both by the IP regime and those supporting the critical access to knowledge (A2K) movement. While the IP regime criticises the criminal aspects of the practice and its alleged threat to creativity, proponents of $\mathrm{A} 2 \mathrm{~K}$ have reservations about piracy's commercial and non-productive side. In order to understand its full complexity, Liang (2010) proposes that when it comes to piracy, people should focus on what it does 
rather than what it is. Paradoxically, the bazaar actors are unable to do precisely that. Although piracy offers a livelihood, the small-scale traders find it difficult to see it merely as a source of income.

\title{
Piracy is similar to stealing! (Piracy chori ke barabar hain)
}

In Nehru Place, Vivek sells pirated DVDs/CDs of computer games and installs cracked games in personal computers. Based on his skill and reputation, Vivek manages to obtain a decent income. Yet Vivek does not accept piracy as the right path to earn a living. He tells me that piracy amounts to stealing from people their due share of profit. Vivek gives me a detailed account of what he thinks is the immediate result of 'copying' on other market actors. He agrees that Microsoft is a big company with a good yearly turnover. But according to him, good business happens mostly in the US. Vivek argues,

\begin{abstract}
We have a Microsoft office (points to a multi storied building) right next to the market. Thousands of employees have to meet monthly targets. Otherwise, they get fired from their jobs. It is only the top-level executives whose jobs are secure. Indians hardly ever rise to those positions. Indians are usually the foot soldiers without any real power. We are not surprised therefore, when we get raids from the police prompted by Microsoft officials. We are directly responsible for the downward spiral of prices. But what can we do! We also have to earn a living.
\end{abstract}

Furthermore, he contemplates,

Year after year, Microsoft is spending thousands of dollars on producing games and software and spending more money to build security systems. Hackers destroy all their work in one second. Then the pirated DVDs reach the markets. We sell software for less than half the Microsoft's price. This is stealing from the company.

\section{Those who are mechanics do not have degrees! (Jo mechanics hain un logo ke paas degree nahi hote)}

One day at Palika, a repair-person talks about why he cannot become a successful programmer. Lalit says,

Have you seen the expensive machines the programmers use to build software! The successful programmers get to work with the most powerful computers in the world. We are here working with screwdrivers and borrowed tools. I can never reach the stage of efficiency that a skilled software programmer has. We are merely mechanics copying the inventions of others. There is no originality in the market.

The repair-person goes on to talk about various small time innovations in the market, particularly describing the process of tinkering with old consoles and gaming devices. To his mind, the process of tinkering is not the same as working with brand new machines that qualified engineers operate. His dissatisfaction is as much about the process of doing things as about the stage at which a person gets to enter a creative process. In his mind, bazaar traders are like mechanics who get to work with finished goods, and are not involved in the creative process. Lalit opines that his lack of professional qualifications prevents him from being part of an ideational team.

\section{Calculation and bazaar ethics}

Delhi's bazaar calculation revolves around commercial transactions. First and foremost, the traders are concerned with their own survival. The traders' everyday market transactions are not governed by altruistic motives. They are in constant competition with one another. In fact, each shop assigns a young man to attract new consumers before his neighbour can. However, if the situation demands, the traders also come to each other's aid. The possibility of co-existence is a coveted market action. Nobody in the bazaars wants to come across as a blood sucking capitalist. One of the worst insults to say to someone is that he is lalchi (greedy). Money is important in the market, but to be seen as 
someone who is running only after money is degrading. When it comes to market transactions, even going as far as wooing other shops' customers is seen as fair play. However, what is not appreciated is going behind others' backs and plot against them to make unbridled profit. Competition is accepted in the markets, but not dishonesty and deceit.

The search for an ethical being embedded in stories from religious texts and folklore inhibits the traders from seeing the figure of a ruthless businessman as a moral one. In fact, big businesses emerge as unjust. Traders criticise companies such as Reliance and Tata that are willing to incur momentary loss in order to wipe out other competitors. As such, based on the everyday ethics of the bazaar, a desirable market actor is one who is frugal and conscientious.

However, the traders struggle to see any ethical sense in selling pirated goods. In their free time, many traders discuss what they do to earn a living. They are unhappy to be working with pirated products. In this regard, the traders refer not just to the legal definition of piracy but also they take into account its cultural connotation. In the examples above, stealing and legitimate qualifications are obstacles to appreciating piracy as a valid source of income. Chori, or stealing as the traders put it, is not simply a part of neoliberal jargon. There are strong moral connotations to being branded a cheat in India. Even if we take a common example from Bollywood (the Hindi Film industry), then referring to someone as 420 is an insult (the Article 420 in the Indian constitution refers to cheating and dishonesty in the manner of appropriating property that is not one's own). This is exactly the sentiment that Vivek evokes when he discusses his own involvement with the selling of pirated products. He is constantly preoccupied with the concern that he is taking someone else's profit and that does not put him in a good light.

Again, working with pirated products making someone a mechanic is an idea rooted in the ethical universe of the just profession. In popular culture, mechanics are always seen as less qualified persons. Assuming that Bollywood mirrors this complex collective ethos, an iconic image from the movies of the 1970s was of a greasy hardworking car mechanic sliding from the bottom of a car to confront a suit laden white-collar professional. In one sense, the traders visualising tinkering as mechanical upholds the contrast between the image of a blue collar and a white-collar worker. Piracy, and more so, the cracking of gaming consoles, are about hands-on knowledge and not about posh offices and professional knowledge. This leads the traders to see tinkering in an ambiguous light.

Broadly speaking, the ethics of honesty and professional knowledge can be traced back to the modernising project in India. The Nehruvian era emphasised the expansion of scientific and technological knowledge without losing sight of more traditional values (Banerjee 1998). At some level, the traders' emphasis on attaining valid knowledge while at the same time being moral beings was fostered by the complex modernising project, where modern values (entrenched by colonialism) co-existed with local belief systems (Kaviraj 2000).

Certainly, the ideas of ownership and legitimate skills have become more vocal and forceful with a neoliberal discourse (Dent 2012). However, the ethical universe of the traders harks back to earlier times, particularly the post-independence period when a complex ideology of scientific knowledge and traditional values was engrained in the makings of a modern self.

\section{Conclusion}

This article has tried to discuss the short-term calculation that is part of Delhi's electronic bazaars. From day-to-day bookkeeping to bargaining practices, the calculation of accounts, prices, and uncertainties is geared towards everyday survival. I have further investigated how short-term calculation takes place within an everyday ethical universe. I analyse moral stories as legitimising the traders' search for small profits. In contrast, the ethical values associated with piracy prompt traders to critically evaluate their trade.

In conclusion, I want to touch briefly on the connection between market calculus and the longue durée of capitalism, a broad concept around which the politics and future of these bazaars has been 
imagined. Undoubtedly, capitalism is the dominant economic system of our times. Our leisure habits, desires, and workspaces are subsumed by capital. The bazaars are no exception. Big corporations adversely affect the business of the bazaars. Within an environment of proprietary regimes and an increase in shopping malls, showrooms, and online e-commerce sites, the bazaars have a smaller number of consumers.

While at the macro level capitalism affects the future potential of the bazaars, at the micro level it is the possibility of reproducing the time tested 'regular, predictable, routine' that motivates market actors. The small-scale traders' continuation of an economy of face-to-face market exchanges makes it relevant to speak of the different layers of economic and social life. What glues together a bazaar's way of life is the negotiations that the traders have with the people coming to the market, and the everyday ethical universe that they are part of. The traders sustain their trade by responding to bargaining cues, nurturing trade networks and settling dues at the end of the day.

The analysis of a particular economic system enables us to see the intricacies of life within an overarching capitalist mode of production. By focusing on Delhi's bazaar economy, highly particular ethics come to light that in turn create a frugal market actor. At the same time, these ethics prevent him from actively challenging the dominant proprietary regime. Or rather, the ethical life leads to a certain type of market actor, who does not organise with fellow traders to resist the structures that marginalise bazaar trade.

\section{Disclosure statement}

No potential conflict of interest was reported by the authors.

\section{Funding}

This work was partially supported by the research project P2PValue, funded European Commission [grant agreement 610961].

\section{Notes on contributor}

Maitrayee Deka is a Postdoctoral Fellow in the Department of Social and Political Sciences at the University of Milan.

\section{References}

Amin, N., 2002. The informal sector in Asia from the decent work perspective. [online]. Available from: http://www.ilo. org/dyn/infoecon/docs/39/F1938403916/Asia\%20amin\%20\%20mine.pdf [Accessed 18 February 2013].

Appadurai, A., 2011. The ghost in the financial machine. Public Culture, 23 (3), 517-539. doi:10.1215/089923631336399

Appadurai, A., 2012. The spirit of calculation. The Cambridge Journal of Anthropology, 30 (1), 3-17. doi:10.3167/ca. 2012.300102

Arnoldi, J., 2004. Derivatives: virtual values and real risks. Theory, Culture \& Society, 21 (6), 23-42. doi:10.1177/ 0263276404047414

Babb, L.A., 1987. Redemptive encounters: three modern styles in the Hindu tradition. Berkeley: University of California.

Banerjee, N., 1998. Whatever happened to the dreams of modernity? The Nehruvian era and women's position. Economic and Political Weekly, 33 (17), WS2-WS7.

Beckert, J., 2013. Imagined futures: fictional expectation in the economy. Theory Culture \& Society, 42 (3), $219-240$. doi:10.1007/s11186-013-9191-2

Birla, R., 2010. Vernacular capitalists and the modern subject in India: law, cultural politics, and market ethics. In: A. Pandian and D. Ali, eds. Ethical life in South Asia. New Delhi: Oxford University Press, 83-100.

Birla, R., 2011. Stage of capital: law, culture and market governance in late capital India. New Delhi: Orient Blackswan.

Braudel, F., 1977. Afterthoughts on material civilization and capitalism. Baltimore, MD: John Hopkins University Press.

Braudel, F., 1981. Civilisation and capitalism, 15th-18th century, I: the structures of everyday life. New York: Harper \& Row.

Braudel, F., 1982. Civilisation and capitalism, 15th-18th century: the wheels of commerce. New York: Harper \& Row. 
Braudel, F., 1984. Civilisation and capitalism, 15th-18th century, III: the perspective of the world. New York: Harper\& Row.

Callon, M., 1998. The laws of the markets. Malden, MA: Blackwell Publishers.

Callon, M. and Muniesa, F., 2005. Peripheral vision: economic markets as calculative collective devices. Organization Studies, 26 (8), 1229-1250. doi:10.1177/0170840605056393

Cochoy, F., 2007. A sociology of market-things: on tending the garden of choices in market retailing. The Sociological Review, 55 (2), 109-129. doi:10.1111/j.1467-954X.2007.00732.x

Dent, A.S., 2012. Piracy, circulatory legitimacy, and neoliberal subjectivity in Brazil. Cultural Anthropology, 27 (1), 2849. doi:10.1111/j.1548-1360.2012.01125.x

Esposito, E., 2011. The future of futures: the time of money in financing and society. London: Elgar.

Geertz, C., 1963. Peddlers and princes: social development and economic changes in two Indonesian towns. Chicago, IL: University of Chicago Press.

Geertz, C., 1978. The bazaar economy: information and search in peasant marketing. The American Economic Review, 68 (2), 28-32.

Goody, J., 1996. The east in the west. Cambridge: Cambridge University Press.

Graeber, D., 2001. Towards an anthropological theory of value: the false coin of our own dreams. New York: Palgrave.

Kalyani, M., 2015. Unorganized workers: a core strength of the Indian labour force: an analysis. International Journal of Research in Business Studies and Management, 2 (12), 44-56.

Kaviraj, S., 2000. Modernity and politics in India. Daedalus, 129 (1), 137-162.

Knight, F.W., 1921. Risk, uncertainty and profit. New York: Houghton Mifflin.

Langlois, R.N. and Cosgel, M.M., 1993. Frank knight on risk, uncertainty, and the firm: a new interpretation. Economic Inquiry, 31 (3), 456-465. doi:10.1111/j.1465-7295.1993.tb01305.x

Liang, L., 2010. Beyond representation: the figure of the pirate. In: A. Kapczynski and G. Krikorian, eds. Access to knowledge in the age of intellectual property. New York: Zone Books, 277-292.

Lobato, R., 2014. The paradoxes of piracy. In: L. Eckstein and A. Schwarz, eds. Postcolonial piracy: media distribution and cultural production in the global south. London: Bloomsbury Academic, 121-134.

Madan, T.N., 1987. Non-renunciation: themes and interpretations of Hindu culture. Delhi: Oxford University Press.

Marazzi, C., 2008. Capital and language: from the new economy to the war economy. Los Angeles, CA: Semiotext(e).

Pandian, A., 2010. Interior horizons: an ethical space of selfhood in South India. Journal of the Royal Anthropological Institute, 16 (1), 64-83. doi:10.1111/j.1467-9655.2009.01597.x

Polanyi, K., 1975. The great transformation: the political and economic origins of our times. New York: Octagon Books.

Sundaram, R., 2010. Pirate modernity: Delhi's media urbanism. New York: Routledge.

Vidal, D., 2000. Markets and intermediaries: an enquiry about the principles of market economy in the grain market of Delhi. In: V. Dupont and E. Tarlo, eds. Delhi: urban spaces and human destinies. Delhi: Manohar, 125-142.

Vidal, D., 2003. Markets. In: V. Das, ed. The oxford Indian companion to sociology and social anthropology. New Delhi: Oxford University Press, 1342-1360.

Weber, M., 2001. The protestant ethic and the spirit of capitalism. London: Routledge. 